УДК $821.112 .2-32.09(092)$

C34

Сивик Оксана, кандидат педагогічних наук, старший викладач

Навчально-науковий інститут іноземних мов Дрогобицький державний педагогічний університет імені Івана Франка

\title{
СПЕЦИФІКА НОВЕЛИ В ЛІТЕРАТУРНІЙ СПАДЩИНІ ВІЛЬГЕЛЬМА ГАУФА
}

У статті досліджуються характерні риси новелістики та аналізується новелістична творчість німецького письменника Вільгельма Гауфа. Творчість Вільгельма Гауфа займає особливе місие в літературному прочесі Німеччини. Виникнувши на зламі епох, а саме в кіниі «естетичного періоду»,в його творчості відбились риси перехідного часу, які 
поєднували в собі різнорідні стильові тендениії, щуо дозволяли бачити в ній важливі ланки національної історії розвитку жанру. Вільгельм Гауф увійшов в історію літератури, пери за все як казкар, але в його казковій творчості відчуваються тенденції іншої художньої мови та іншої жанрової форми, які потребують дослідження.

Ключові слова: новела, література, творчість, літературний процес, стиль, тенденція, жанр, казка.

\section{Syvyk O. The specificity of novel in the literary heritage of Wilhelm Hauff.}

The article examines the characteristic features of the novels and analyzes the novelistic works of the German writer Wilhelm Hauff. The work of Wilhelm Hauff occupies a special place in the literary process in Germany. Having emerged at the turn of epochs, namely at the end of the "aesthetic period", his work reflected the features of the transitional time, combining heterogeneous style tendencies, and makes it possible to see in it important links in the national history of the development of the genre. Wilhelm Hauff entered the history of literature, primarily as a storyteller. But in his fabulous creativity one senses the tendencies of another artistic language and another genre form.

Key words: novel, literature, creativity, literary process, style, trend, genre, fairy tale.

Вільгельму Гауфу належить особливе місце в історії німецької літератури XIX століття. Незважаючи на величезну кількість блискучих зразків жанру, створених визнаними метрами романтичної епохи Л. Тиком, Г. Клейстом, А. Арнимом, Е. Т. А. Гофманом і ін., молодому швабському письменникові довелося зайняти свою «нішу» в літературі Німеччини.

Літературна спадщина письменника не була багатою та визначною, але стала важливим етапом у розвитку німецького літературного процесу. Зберігаючи відгомони романтичної епохи та вбираючи характерні риси високої словесності і рядовий белетристики свого часу, творчість В. Гауфа стає підготовчим етапом для зародження реалістичної естетики.

Молодий автор творить на зламі літературних пластів, його творчість стає явищем в багатьох сенсах прикордонним. Адже, вона знаходиться на межі романтизму і бідермаєра, класики і масової літератури, наслідування і пародії. Новела В. Гауфа являє собою складне жанрове утворення. Новела В. Гауфа прагне до повісті і навіть до роману, що, перш за все, виражається в збільшенні обсягу. Сувора жанрова композиція руйнується завдяки ретардації (властивої ще романтичної новелі) і включення в текст різноманітних тривалих бесід (що, зокрема, було характерно для стилю бідермаєр). Таким чином, в новелі 
В. Гауфа зникає зосередженість дії навколо центральної події, а, отже, не дотримується один з основних принципів новелістичної композиції.

Новелу В. Гауфа характеризують також особливості, властиві повісті або роману: часта зміна оповідних планів, наявність в ранніх новелах безлічі фабульних ниток, які можна виділити як самостійні новели також традиційне положення в фіналі: чотири 3 шести новел закінчуються весіллям, а дві загибеллю героя, $є$ розгорнуті обговорення персонажами важливих проблем, які подаються з різних точок зору.

В контексті літератури епохи новела В. Гауфа представляє безперечну цінність для читача i літературознавця. 3 огляду на деякі незручні похибки i навіть явні недоліки новел молодого письменника, хочеться підкреслити, що новели В. Гауфа знаменували собою появу нового етапу в естетичному освоєнні дійсності і тому заслуговують більшої уваги з боку дослідників.

Новели В. Гауфа мало перекладались українською мовою і ніколи не перевидавалися. До початку XX століття було перекладено тільки чотири з них: «Отелло» - 1835, «Таємниці Бьянетти» («Співачка») - 1855, «Портрет імператора»-1903 і «Жебрачка з Моста мистецтв»- 1906.

Ряд дослідників вважають новелістичну творчість В. Гауфа гідною пильної уваги. Серед них Р. М. Самарін [21, с. 26], В. П. Неустроєв [5, с. 259], М. І. Бент [1, с. 119], А. Б. Ботнікова [3, с. 319]. Ці вчені розглядають творчість В. Гауфа як ланку в художньому розвитку жанру новели в Німеччині, як перехідний, необхідний i важливий етап в історії німецької літератури. Потрібно зазначити, що українському читачеві його ім'я майже невідоме, в нашому літературознавстві творчість його також практично невивчена, тому важливим етапом статті $є$ дослідження творчості відомого австрійського письменника В. Гауфа.

Мета статті - визначиння особливої ролі і місця новелістики В. Гауфа в історії розвитку жанру новели в німецькій літературі.

Основні завдання статті вбачаємо у визначенні місця новелістичного жанру в творчому доробку письменника, відомого більше як автора казок, у 
розкритті їх своєрідності у порівнянні 3 досвідом попередників (Е. Т. А. Гофмана, А. Арнима і ін.), у дослідженні новелістики письменника, показавши іiі тематичну і жанрову своєрідність та у встановленні зв'язку новел В. Гауфа зі стильовими пошуками його часу.

Вільгельм Гауф є відомим у всьому світі, перш за все, як казкар. Важливо i те, що він пробував себе i в інших жанрах. Цей безперечно обдарований художник слова не дожив до свого двадцятип'ятиріччя, найімовірніше, не встигнувши повною мірою розкрити свій талант. Творча діяльність В. Гауфа охоплює дуже короткий період - два 3 половиною роки. Його спадщина включає в себе не тільки знамениті в усьому світі три казкових збірки, але також три романи, цілий ряд статей, нарисів і шість новел.

Не слід також забувати про місце письменника в літературному процесі Німеччини. В. Гауф творив на кордоні літературної епохи, коли вигадливо перепліталися різноманітні стильові тенденції. У цій строкатості він безперервно шукав свою манеру. Тому важко зарахувати його до якогось одного 3 відомих літературних напрямів або стилів епохи. Письменник відштовхувався від попередників. Частково наслідуючи романтиків (особливо, Е. Т. А. Гофмана і Л. Тика), вбираючи риси сучасного йому стилю бідермаєр, нерідко пародіюючи белетристику свого часу (перш за все, Г. Клаурена, Г. Цшокке), запозичуючи іï прийоми, В. Гауф прагне до нової, ще не освоєної художньої практики реалістичної естетики. Це найбільш чітко помітно на прикладі тих творів, котрих сам автор називає новелами. Вони належать до малої форми, але в жанровому плані кожна 3 них відрізняється своєрідністю. Звернення В. Гауфа до жанру новели цілком закономірне. Адже, саме жанр новели був широко поширений в німецькій літературі першої половини XIX століття. Чи не всі автори тієї епохи писали новели. А. Арнім, К. Брентано, Г. Клейст, Л. Тік, Е. Т. А. Гофман, Й. Ейхендорфа, Е. Меріке, В. Алексіс створили прекрасні зразки цього жанру, які завоювали величезну популярність ще за свого життя письменників, і в більшості своїй не забуті і по сьогодні. 
У роки вступу В. Гауфа в літературу новела стала чи не найбільш улюбленим жанром. Така перевага була цілком з'ясована. Масовий читач того часу мав потребу саме в невеликих оповіданнях, барвистих альманахах та інших захоплюючих і коротких штучках. Публіцист Т. Мундт писав, що до 30-х років XIX століття «новела стає німеиькою $і$ в цій іпостасі покликана грати роль вищої форми мистецтвва» [23, с. 71]. У той же час, до початку XIX століття, і саме в Німеччині, новела сформувалася як серйозний, самостійний і самобутній жанр.

3 часу свого виникнення жанр новели постійно видозмінювався. Перші новели обов'язково володіли несподіваною кінцівкою, до того ж містили в собі соціальну критику. Їх героями були спритні люди, які майже завжди з легкістю виходять зі скрутних ситуацій. Іноді новели середньовіччя і Відродження оповідали про різні проступки і злочини церковнослужителів. Все це цілком відповідало вимогам епохи Ренесансу.

Новели зазвичай відрізнялися стислістю і в середньому вміщалися на двох-трьох аркушах. Характери героїв не були докладно прописані, як правило, не приділялося особливої уваги душевним шуканням персонажів, їх внутрішній світ мало цікавив авторів, а якщо і цікавив, то розкривався через вчинки героїв, а не за допомогою розлогих коментарів.

За часів пізнього Відродження, а також в XVII-XVIII століттях, відбувається романтизація новели. Обсяг твору збільшується за рахунок побутових сцен, опису різноманітних пригод героїв, за рахунок психологізму. Німецька романтична новела - особлива сторінка в історії європейської новелістики. Незважаючи на те, що відправною точкою для німецьких романтиків було знамените гетевське визначення жанру як «нечуваної події» («eine unerhörte Begebenheit») [11, с. 221], вони сильно видозмінили цей жанр, в основному за рахунок того, що «нечувана подія» найчастіше подавалася за допомогою фантастичного елемента, а сама новела часом тяжіла до казки, міфу, філософської притчі. При цьому романтична новелістика була різнорідна i різноманітна. Вона в рівній мірі стосувалася і таємниць буття, і глибин 
людської психології. Фантастичний елемент використовується В. Гауфом тільки для прикраси і залучення більшої уваги з боку читаючої публіки. У новелі «Отелло» чудо присутнє лише уві сні головної героїні. Це не більше ніж данина романтичної традиції. У тринадцяту главу «єврея Зюсс» вкрапляєтся цілий ряд фантастичних елементів, тут є i страшні ознаки, i ірраціональне пояснення смерті герцога. Однак всі ці містичні атрибути зібрані на декількох сторінках, в той час як основний текст новели позбавлений будь-яких чудес.

Безумовно, молодий, початківець автор, будучи аж ніяк не байдужий до популярності, що пробував себе в різних якостях і як казкар, і як романіст, і як публіцист, просто не міг не віддати данину моді i не спробувати щастя на терені новеліста. Не можна сказати, однак, що новела В. Гауфа мала дуже великий успіх у публіки. За життя набагато більш популярні були його романи. Однак новелістична частина його творчості для читача того часу все ж представляла певний інтерес.

У порівнянні з попереднім етапом розвитку жанру, новела В. Гауфа являє собою щось нове. Перш за все, тому, що вона, як ніколи раніше, спирається на навколишню дійсність, часом навіть критикуючи якісь іï моменти. У текстах Гауфівскої новели втручаються різного роду описи, роздуми, ліричні відступи. Персонажі починають набувати не тільки свого характеру, але, часом, i індивідуальні мовні характеристики.

Письменник створив всього шість новел: «Отелло» (1825), «Жебрачка 3 моста мистецтв» (1825), «Співачка» (1826), «Сврей Зюсс» (1826), «Останні лицарі Марієнбурга» (1827) і «Портрет Імператора» (1827). До цього можна додати ще «Прокляття» - вставну новелу в «Мемуарах Сатани». Абсолютна більшість літературознавців виділяють «Портрет Імператора» - останню новелу письменника як найбільш сильний і зрілий його твір в жанрі новели.

Літературну творчість В. Гауфа не можна назвати улюбленим об’єктом вивчення дослідників. Зазначалося, що новелістика В. Гауфа відчувала вплив Г. Клаурена (М. Дрешер), Г. Цшокке (М. Мендгейм, М. Дрешер, Я. Арнаудоф), В. Скотта (М. Дрешер, С. Нейгауз, А. Маннгеймер і ін.), Ф. Шіллера 
(С. Нейгауз), Е. Т. А. Гофмана (М. Дрешер, М. Мендгейм, Й. Клейн та ін.) та інших відомих письменників. Те ж саме відображено і в довідковій літературі $[17$, c. 153$]$.

С. Нейгауз в монографії «Вільгельм Гауф. Гра 3 читачем» (2002) стверджує, що чи не всі літературознавці, які вивчали новели молодого німецького автора, відгукувалися про них негативно, називаючи в числі захисників юного художника слова лише одного Г. Козелека [18, с. 46]. Однак це не зовсім вірно.

У багатьох літературних енциклопедіях і загальних працях 3 німецької літератури підкреслюється значення новелістики В. Гауфа та часто їй дається позитивна оцінка $[20$, с. 505; 6, с. 345; 7, с. 309]. Лише деякі дослідники виділяли новели письменника як кращу або навіть головну частину творчості письменника. До таких дослідників можна віднести К. Хаммера [12, с. 309] i М. Мендгейма. Останній сказав, що: «справжнього апогею муза Гауфа досягла в новелі, де він показує взірець довершеності» [16, с. 22]. У сучасному літературознавстві все частіше спостерігається прагнення знову звернутися до новел В. Гауфа [22, с. 57]. Деякі вчені, а саме Г. Козелек [15, с. 19], С. Нейгауз [18, с. 46], Г. Плумпе [19, с. 105], розглядають багато новел письменника не як наслідування, а як пародію на модну белетристику того часу, вважаючи, що більшість літературознавців несправедливо применшують талант письменника $\mathrm{i}$ значення його новел. Останні роботи дослідників свідчать про те, що новели письменника продовжують залишатися актуальними і не до кінця вивченими.

У цілому, твердження згаданих дослідників не позбавлене підстави. Дійсно, від новели до новели майстерність письменника вдосконалюється, і в трьох останніх зразках цього жанру «Жебрачка 3 Моста мистецтв», «Останні лицарі Марієнбурга», «Портрет Імператора» ми спостерігаємо вже виразно рух автора до відбиття життєвої правди. Однак щодо новел В. Гауфа навряд чи можна говорити про «тонку і складну передачу почуттів». Хоча письменник i прагнув до індивідуалізації образів, що йому певною мірою вдалось, все ж його характеристикам не властивий глибокий психологізм. 
Найбільш грунтовними вітчизняними роботами, в яких розглядається творчість В. Гауфа, є монографії М. І. Бента «Німецька романтична новела. Генезис, еволюція, типологія» (1987) і А. Б. Ботнікова «Німецький романтизм: Діалог художніх форм» (2004).

У дослідженні М. I. Бента новелістиці В. Гауфа відводиться окремий розділ, в якій вчений розглядає «тенденцію в розвитку жанру новели в рамках творчості письменника і всього мистецтва бідермаєра» [1, с. 96] на прикладі трьох новел: «Співачка», «Жебрачка з Моста мистецтв» і «портрет Імператора». Дослідник в динаміці простежує становлення В. Гауфа як новеліста, зазначає посилення від новели до новели реалістичних тенденцій, в цілому уникаючи прямих оцінок розглянутих творів.

А. Б. Ботнікова в одній із глав своєї монографії робить огляд творчості В. Гауфа, детально зупиняючись на найбільш значущих творах письменника. В iï роботі розглядається «Жебрачка 3 Моста мистецтв», «Єврей Зюсс» i «Портрет Імператора». Дослідниця бачить цінність новел В. Гауфа в тому, що вони «міцно пов'язані із сьогоднішнім днем, його справами, турботами, людськими інтересами i формами поведінки» [3, с. 317]. «Його [Гауфа] новелістика - живе свідчення того, як актуалізуються прозові форми в процесі живого розвитку літератури» [3, с. 317] - пише А. Б. Ботнікова.

Отже, літературна спадщина В. Гауфа виявляється майже повною відмовою від всього чудесного і фантастичного. В. Гауф є першим німецьким автором, який повернув новелу 3 «романтичних сфер» «чарівного» i «казкового» на «орбіту» буденності. Якщо в творчості «класичних» представників романтизму кордони між новелою і казкою часто бувають розмиті, то В. Гауф намагався виокремити саме жанр новели. Він не виключає присутності «дивних» явищ в сюжеті новели, але прагне все-таки до іiі відокремлення від казки. Заявлена тема дослідження $\epsilon$ перспективною для подальшого вивчення поетики жанру новели. 


\section{Література}

1. Бент М. Немецкая романтическая новелла. Генезис, эволюция, типология / М. Бент. - Иркутск : Издательство Иркутского университета, 1987. $-119 \mathrm{c}$.

2. Белинский В. Г. Собрание сочинений: В 9-ти тт. / В. Г. Белинский Т. 1. Статьи, рецензии и заметки 1834-1836. - М. : Художественная литература, 1976. - C. $138-184$.

3. Ботникова А.Б. Немецкий романтизм : Диалог художественных форм / А. Б. Ботникова. - Воронеж : Изд-во ВГУ, 2004. - 340с.

4. Гауф В. Еврей Зюс / В. Гауф. - М. : Российский писатель, 2002. $128 \mathrm{c}$.

5. Неустроев В. П. Гауф / В. П. Неустроев, Р. М. Самарин // История немецкой литературы в 5 т. - М. : Наука, 1966. - Т. 3 (1790-1848). - С. 256-265.

6. Deutsche Literaturgeschichte in Bildern. Eine Darstellung von den Anfangen bis zur Gegenwart. - Leipzig : VEB Bibliographisches Institut. MCMLXIX. - s. 345.

7. Deutsche Literaturgeschichte in einem Band. - Berlin: Volk und Wissen Volkseigener Verlag, 1971. -768 S.

8. Der Große Brockhaus. Handbuch des Wissens: in 20 Bd. Bd. 8, Leipzig, 1931. - s. 227.

9. Drescher M. Einleitung des Herausgebers / M. Drescher // Hauffs Werke in sechs Teilen., Teil 5. - Berlin - Leipzig - Wien -Stuttgart : Deutsches Verlagshaus Bong \& Co. - S. 45-57.

10.Drescher M. Einleitung / M. Drescher // Hs Werke 1 Teil; hgg. von M. Drescher. - Berlin-Leipzig-Wien-Stuttgart (Märchenalmanache). - S. 7-19.

11.Eckermann J. P. Gespräche mit Goethe. In den letzten Jahren seines Lebens; hgg. v. C Michel unter Mitwirkung v. H. Graters / J. P. Eckermann. Frankfurt, a. M., 1999. - 283 s.

12.Hammer. K. Wilhelm Hauff / K. Hammer // Deutsche Literaturgeschichte in einem Band. - Berlin: Volk und Wissen Volkseigene Verlag, 
1971. - s. 309.

13.Hofmann H. Wilhelm Hauff. Eine nach neuen Quellen bearbeitete Darstellung seines Werdeganges / H. Hoffman. - F. a M. : Moritz Diesterweg, 1902. $-298 \mathrm{~s}$.

14.Klein J. Geschichte der deutschen Novelle von Goethe bis zur Gegenwart. 3. - Aufl. / J. Klein. - Wiesbaden, 1956. XVIII - 614 s.

15.Kozielek G. Das novellistische Schaffen Wilhelm Hauffs / G. Kozielek // Lenau-Almanach, 1976-1978. - S. 19-28.

16. Mendheim M. Wilhelm Hauffs Werke / M. Mendheim. - 1 Bd. - Leipzig u. Wien: Bibliographisces Institut, 1891. - S. 1-32.

17.Meyers Neues Lexikon: in 18 Bd. Bd.6. - Leipzig : VEB Bibliographisches Institut. - S. 153-154.

18. Neuhaus S. Hauffs Werke. Das Spiel mit dem Leser. Wilhelm Hauff. Werk und Wirkung/S. Neuhauss. - Göttingen : Vandenhoek \& Ruprecht, 2002. - 240 s.

19.Plumpe G. Theorie des bürgerlichen Realismus. / G. Plumpe. - Stuttgart : Reclam, 1985. - $351 \mathrm{~s}$.

20.Reimann P. Hauptstromungen der deutschen Literatur 1750-1848. Beitrage zu ihrer Geschichte und Kritik. / P. Reiman. - Berlin: Diety Verlag, 1963. - 839 s.

21.Samarin R. M. Deutsche Novellen des 19. Jhs. / R. M. Samarin. - Moskau : Verlag für fremdsprachige Literatur, 1959. - S. 3-29.

22. Stockinger C. Verkährungen der Romantik. Hauffs Erzählungen im Kontext frührealistischer Verfahren / C. Stockinger // Wilhelm Hauff oder Die Virtuosität der Einbildungskraft. - Göttingen: Wallst ein Verlag 2005. - 384 s.

23. Theorie und Kritik der deutschen Novelle von Wieland bis Musil. Tübingen, 1970. - $199 \mathrm{~s}$. 